\title{
Listeria monocytogenes exists in at least three evolutionary lines: evidence from flagellin, invasive associated protein and listeriolysin 0 genes
}

\author{
Ole F. Rasmussen, ${ }^{1} \nmid$ Pernille Skouboe, ${ }^{1}$ Lone Dons, ${ }^{1,2}$ Lone Rossen ${ }^{1}$ and \\ John E. Olsen²
}

Author for correspondence: Ole F. Rasmussen. Tel: +45382733 03. Fax: +4538272727.

1 Biotechnological Institute,
Lundtoftevej 100, Building
227, DK-2800 Lyngby,
Denmark
2 Department of Veterinary
Microbiology, The Royal
Veterinary and
Agricultural University,
Bulowsvej 13, DK-1870
Frederiksberg C, Denmark

\begin{abstract}
Regions of the genes encoding flagellin (flaA), the invasive associated protein (iap), listeriolysin $\mathrm{O}(\mathrm{h} / \mathrm{y})$ and 235 rRNA were sequenced for a range of Listeria monocytogenes isolates of different origin and serotypes. Several nucleotide sequence variations were found in the flaA, iap and $h l y$ genes. No differences were found for the rRNA genes, but our approach does not exclude the existence of differences between single copies of these genes. Based on the sequence differences, the $L$. monocytogenes strains can be divided into three distinct sequence types. Further, the presence of only a small number of sequence differences within each group indicates a strong degree of conservation within the groups. There was a complete correspondence among the groups of strains formed according to the analysis of the flaA, iap and hly genes, and the grouping correlates with serotype, pulsed field gel electrophoretic and multilocus enzyme electrophoretic data. Analysis of the region encoding the threonine-asparagine repeat units in the iap gene revealed some striking features. Sequence type 1 strains were found to have 16-17 repeats, sequence type 2 strains had 16-20 repeats whereas the two sequence type 3 strains analysed had only 11 repeats. Furthermore, within a 19 bp segment there was a $37 \%$ difference between the sequences of type 1 and 2 strains and that segment was absent in type 3 strains. Within the threonine-asparagine repeat region the nucleotide differences gave rise to four amino acid changes; however, all were changes among the three amino acids present in the repeat structure indicating a strong selective pressure on the composition of this region.
\end{abstract}

Keywords: clonality, evolutionary lines, flagellin gene, haemolysin gene, invasive associated protein gene

\section{INTRODUCTION}

The Gram-positive bacterium Listeria monocytogenes is widespread in the environment and may invade humans and animals where it behaves as a facultative intracellular pathogen (Seelinger \& Jones, 1986). From the port of

†Present address: Radiometer Medical AV, Ảkandevej 21, DK-2700 Brønshøj, Denmark.

Abbreviations: MLEE, multilocus enzyme electrophoresis; RAPD, random amplified polymorphic DNA.

The EMBL accession numbers for the sequences reported in this paper are listed in Table 1. entrance, listeriosis can develop into severe invasive diseases, including septicaemia and meningitis, primarily in immunocompromized individuals, neonates and foetuses (McLauchlin, 1987). Over the last decade there have been several food-associated outbreaks of listeriosis (Fleming et al., 1985; Linnan et al., 1988), and L. monocytogenes is now recognized as an important foodborne pathogen.

Several molecular methods have been employed for the characterization of $L$. monocytogenes strains. Using multilocus enzyme electrophoresis (MLEE), Bibb et al. (1990) found that 390 isolates of 6 different serotypes could be grouped into two distinct clusters of electrophoretic types 
and that the clusters coincided with the flagellar types $\mathrm{b}$ ( $\mathrm{ABC} \mathrm{H}$-antigens) and non-b ( $\mathrm{AB}$ or $\mathrm{BD} \mathrm{H}$-antigens) serovars, respectively. Similar results were obtained by Boerlin et al. (1991) and Piffaretti et al. (1989) using the same technique. A somewhat different pattern was found by Tabouret $e$ t al. (1992). Analysing surface proteins by SDS-PAGE, they identified two clusters which correlated with the $\mathrm{O}$-antigen groups, $1 / 2$ serovars and 4 serovars, respectively. Brosch et al. (1991) and Buchreiser et al. (1991) also found a distinction between serotype 1/2 and serotype 4 isolates using PFGE. However, in a recent study with 176 isolates, PFGE could separate the isolates according to flagellar antigens (Brosch et al., 1994).

A new method for strain differentiation is profiling by random amplified polymorphic DNA (RAPD). Using this method on strains of different $L$. monocytogenes serotypes Mazurier \& Wernars (1992) showed that some strains from different serotypes exhibited identical RAPD profiles. However, the RAPD profiles could, in general, differentiate between the isolates according to the flagellar antigens. Only a single profile was shared among isolates with $\mathrm{H}$-antigens $\mathrm{ABC}$ and isolates with other combinations of H-antigens. Furthermore, Vines et al. (1992) have shown that RFLP is able to subdivide $L$. monocytogenes into two distinct groups.

The most precise analytical tool for characterization is DNA sequence analysis, and PCR has now made the characterization of gene segments from a large number of isolates feasible. Using this approach we have previously found that $L$. monocytogenes isolates can be grouped into two major types according to the nucleotide sequence of a segment of the listeriolysin gene, bly. Furthermore, we found a correspondence between this grouping and flagellar antigens (Rasmussen et al., 1991).

To investigate whether the pattern of distinct DNA sequence types also exists outside the bly gene, we have in this report analysed parts of the flagellin gene, fla $A$, isolated by Dons et al. (1992), and the invasive associated protein gene, iap, (Köhler et al., 1990), as well as the 23S rRNA genes. The $f a A$ gene encodes the polypeptide subunits of the flagella filament, and it has been suggested that the invasive associated protein is associated with the invasion of non-professional phagocytic cells (Kuhn \& Goebel, 1989). Moreover, in search of additional sequence types, we have extended the analysis of the bly gene segment to include a total of 77 isolates.

\section{METHODS}

Bacterial strains and growth conditions. A total of $77 \mathrm{~L}$. monocytogenes strains were included in this study (Table 1). Of these strains, 48 were human clinical isolates, and 24 strains were of different animal or environmental (manure, fodder, etc.) origins. The remaining strains were culture collection isolates of unknown origin. There were 44 strains of serotype $1 / 2$, one isolate was serotype 3 , and 32 were serotype $4,4 a$ or $4 \mathrm{~b}$. Bacteria were propagated in brain heart infusion broth overnight at $30^{\circ} \mathrm{C}$ without shaking.

Oligonucleotides. Synthetic oligonucleotides were prepared on a Cyclone DNA Synthesizer according to the manufacturer's instructions (Biosearch). The following primers were used: for the bly gene: LM4 (5'-CAGTTGCAAGCGCTTGGAGT-3'); LM5 (5'-CCTCCAGAGTGATCGATGTT-3') ; LM6 (5'TTGTTTCAATATATTCTGAGT-3'); for the iap gene: LM20 (5'-GAGAAATCTGTTAGCGCAACTTGG-3'); LM21 (5'-CCAT'TACCAACGTAGATACCACG-3'); LM22 (5'-CAGAGATTCTTG'TAGTGC-3'); for the $f a A$ gene: P1 (5'-GATTGTTCCAGCAGAAAGAC-3'); P3 (5'-AAATGAAGATATAATAAAGC-3'); P4 (5'-GCGACTCATACCAGCACC-3'); for the 23S rRNA gene: 23-1104f (5'-AGAAAGCGTAA'TAGCTCAC-3'); 23-1608r (5'-CCACCTGTGTCGGTTT-3'). LM4, LM5, LM20, LM21, P3, P4, 23-1104f and 23-1608r were used as amplification primers, and LM6, LM21, LM22, P1 and 23-1608r were used for sequencing. LM4-LM6 were selected according to Rasmussen et al. (1991); LM20LM22 were selected from Köhler et al. (1990); P1, P3 and P4 were selected from Dons et al. (1992), and 23-1104f and 23-1608r were selected according to Lane (1991).

Asymmetric PCR and DNA sequencing. Asymmetric PCR and DNA sequencing were performed as described previously (Rasmussen et al., 1991). DNA sequences were aligned using the PC Gene Screen Device, version 5.03 (IntelliGenetics).

\section{RESULTS AND DISCUSSION}

\section{The flagellin gene}

A $180 \mathrm{bp}$ region of the $f a A$ gene was sequenced in 27 strains (Table 1). The analysed region covers $125 \mathrm{bp}$ of the N-terminal conserved region (position 623-747) and 55 bp of the variable region (position 748-803) according to the sequence of Dons et al. (1992).

In the $\mathrm{N}$-terminal conserved region, which is assumed to be involved in flagellin export as well as flagellar assembly and shape (Jones \& Aizawa, 1991; Macnab, 1992), four general nucleotide differences which separated the strains into three distinct sequence types were found (Table 2). A total of 22 of the strains had previously been included in the analysis of the bly gene (Rasmussen $e$ t al., 1991), and all strains of the bly sequence type 1 grouped in the same $f l a A$ sequence type. Likewise, all strains of the bly sequence type 2 grouped in the same $f a A$ sequence type, and the two $f a A$ types were consequently assigned the corresponding numbers. The third sequence type included two serotype 4a strains which were not analysed in the former study on $b l y$. In the $125 \mathrm{bp}$ of the N-terminal region they differed from the two other sequence types at one and four positions, respectively. None of the general nucleotide differences gave rise to an amino acid change. Furthermore, in this region two strains were found to have strain-specific differences (Table 3).

The central region, which shows considerable variability among species in both length and amino acid composition, is believed to be responsible for the antigenic variation of the flagellar filament (Jones \& Aizawa, 1991). It was therefore surprising to find only a single strain-specific difference (Table 3) and no general differences in the $55 \mathrm{bp}$ region analysed. For a smaller number of strains an additional $60 \mathrm{bp}$ region at the opposite end of the variable region was sequenced (data not shown), and a single general nucleotide difference between sequence types 1 and 2 was found. This base difference gives rise to an 
amino acid change, a glutamic acid in sequence type 1 strains is replaced with a glutamine in type 2 strains. Complete flagellin sequences have been obtained for three Escherichia coli serovars (Schoenhals \& Whitfeld, 1993) and 10 Salmonella $\mathrm{g} . .$. series serovars (Masten \& Joys, 1993). For both species a much greater variation with several amino acid changes was found in the variable region. A direct comparison to $L$. monocytogenes is, however, difficult, as the variable regions of $E$. coli and Salmonella are approximately 200 amino acids longer (Dons et al., 1992).

\section{The invasive associated protein gene}

The iap gene of strain EGD (serotype 1/2a) is 1452 nucleotides long and has a central part of $400 \mathrm{bp}$ which is specific for $L$. monocytogenes. In this region there is an extended repeat segment which in the EGD strain consists of 19 threonine-asparagine (TN) repeat units separated by two blocks of 3 amino acids each (the ANK and PSK motifs) (Köhler et al., 1990) (Fig. 1). Sequence analysis in this study of the repeat unit and flanking regions showed that the pattern of three DNA sequence types also exists for the iap gene (Table 1). Furthermore, full correspondence among the groups of strains formed according to the sequence analysis of each of the bly (Rasmussen $e t$ al., 1991), $f l a A$ and iap genes was found. Consequently, in the following the term 'sequence type' is used as a general term with no specific gene reference. In the description of specific features below, the segment of the iap gene investigated is divided into three regions according to structural features of the gene.

The region upstream of the repeat region, position 1315-1373 (Fig. 1), was analysed for five sequence type 1, three sequence type 2 , and one sequence type 3 strains. All the type 2 strains had a sequence identical to that of EGD, whereas all type 1 strains differed at three positions (Fig. 1). The differences at position 1358 and 1359 are within the same codon, changing it from an alanine in type 2 strains to an arginine in type 1 strains. The sequence of the type 3 isolate was identical to that of EGD except for an insertion of six nucleotides at position 1360 (Fig. 1).

A total of 26 strains were analysed in a second region, position 1374-1586, containing the repeat units (Fig. 1). From direct sequence alignment it was obvious that there were variations in the number of repeat units among the strains. The serotype 4a strains both had 11 repeat units, sequence type 1 strains had 16 or 17 repeats, whereas sequence type 2 strains had from 16 to 20 repeats (Fig. 2, Table 4). Our data are in accordance with the observations by Bubert $e t$ al. (1992), who found 11 repeats in both a serotype $4 a$ and a serotype $4 c$ isolate and 16 and 19 repeats, respectively, in two different serotype $1 / 2 \mathrm{a}$ isolates.

The sequence with 20 repeats was found in a serotype $1 / 2 \mathrm{cstrain}$ (Fig. 2, Type I), and the extra repeat compared to the EGD strain had the sequence 5'-ACAAAT-3', which is identical to the sequence of the first 5 repeats downstream of the region encoding the ANK motif (position 1394-1423, Fig. 1). The alignment of the sequences from the 26 strains showed that the differences in length were confined primarily to this part of the repeat region with identical repeats. This finding supports the notion of Köhler et al. (1990) that the repeat region has apparently been generated by tandem multiplication of the basic unit ACAAAT. It is further substantiated by the pattern of nucleotide differences in this region. All sequence type 1 strains were found to differ from the sequence of the EGD strain in having a $G$ instead of an $A$ at the third position in all the threonine codons (positions 1414 and 1420 for strains with 16 repeats, and additionally at position 1408 for strains with 17 repeats). Apparently this $A$ to $G$ change occurred before the multiplications of the TN repeats in the sequence type 1 strains. Also, the serotype 4 a strains were found to have a $G$ at the relevant position (position 1420), and four out of the eight sequence type 2 strains had a $G$ at the third position of the first threonine codon after the ANK motif (Table 3).

Atypical repeat structures were found only for the serotype $4 a$ strains and a serotype 1/2a strain which lacks a repeat after the single asparagine between the ANK and PSK motifs (Fig. 2, Type VII). Moreover, it is noteworthy that all four serotype $1 / 2$ strains of sequence type 1 had 17 repeats, whereas all 12 serotype 4/4b strains of sequence type 1 had 16 repeats (Table 4).

There were several other general nucleotide differences in the TN repeat region. There appears to be a hot spot for mutations just downstream of the PSK motif. In this part, which is missing in the serotype 4a strains, a total of seven nucleotide differences were found between the sequence type 1 and sequence type 2 strains within a $19 \mathrm{bp}$ region (Fig. 1). This corresponds to a difference of $37 \%$ in that region. The differences at positions 1443,1472 and $1478 / 1480$ all cause amino acid changes, but only changes among asparagine, threonine and serine (Fig. 2). The serotype 4a strain had 11 nucleotide differences to the EGD strain in addition to the $A / G$ difference at position 1420. These differences gave rise to only one amino acid change, at positions $1496 / 1498$, where a serine in EGD is replaced with a threonine. It is noteworthy that all the amino acid changes within the repeat region are among the three amino acids already present in the repeats: threonine, asparagine and serine. It indicates a strong selective pressure on the amino acid composition of the region. Within the repeat region, no strain-specific nucleotide differences were found within the groups of the sequence type 1 or the sequence type 3 strains, respectively, whereas a few strain-specific differences were found among the sequence type 2 strains (Table 3 ).

In the 79 bp region downstream of the TN repeat region (position 1508-1586, Fig. 1), two general differences between sequence type 1 and sequence type 2 strains as well as two others between sequence type 2 and sequence type 3 strains were found (Fig. 1). Furthermore, the sequences of the type 1 strains were found to differ at position 1549, where 8 out of 16 strains had a $G$ and the rest had an $A$. There may be a correlation between this nucleotide difference and the number of repeats as all the strains with a $G$ at this position had 16 repeats. Within the 
Table 1. L. monocytogenes strains used in this study and their sequence type

Analysis of a specific gene segment is shown by the presence of the corresponding EMBL accession number.

\begin{tabular}{|c|c|c|c|c|c|c|c|}
\hline \multirow[t]{2}{*}{ Strain } & \multirow{2}{*}{$\begin{array}{l}\text { Source or } \\
\text { reference* }\end{array}$} & \multirow[t]{2}{*}{ Serotype $f$} & \multirow{2}{*}{$\begin{array}{l}\text { Sequence } \\
\text { type }\end{array}$} & \multicolumn{4}{|c|}{ Analysed genes } \\
\hline & & & & hly & $f a A$ & $i a p$ & $23 S$ rRNA \\
\hline $1542 \ddagger$ & SS & 4 & 1 & X85816 & & & \\
\hline $3391 \ddagger$ & SS & $4 b$ & 1 & $\mathrm{X} 85817$ & X86993 & & \\
\hline $4521 \ddagger$ & SS & 4 & 1 & X85818 & X86994 & & X85883 \\
\hline 5223 & SS & 4 & 1 & X85819 & & $\mathrm{X} 85860$ & X85884 \\
\hline 5626 & SS & 4 & 1 & $\mathrm{X} 85820$ & X86995 & & X85885 \\
\hline 7595 & SS & 4 & 1 & $\mathrm{X} 85854$ & & $\mathrm{X} 85863$ & X85886 \\
\hline 7751 & SS & 4 & 1 & $\mathrm{X} 85821$ & & $\mathrm{X} 85861$ & X85887 \\
\hline 8160 & SS & 4 & 1 & X85822 & & X85857 & X85888 \\
\hline $8309 \ddagger$ & SS & 1 & 1 & X85823 & X86996 & & X85889 \\
\hline $8819 \ddagger$ & SS & $4 b$ & 1 & X85815 & X86992 & X85864 & X85890 \\
\hline 9050 & SS & 4 & 1 & X85824 & & X85862 & X85891 \\
\hline 9618 & SS & 4 & 1 & X85825 & & X85858 & X85892 \\
\hline 9709 & SS & 1 & 1 & X85826 & & X85867 & X85893 \\
\hline 10165 & SS & 4 & 1 & X85827 & & X85859 & \\
\hline 10511 & SS & 1 & 1 & X85828 & & X85868 & \\
\hline 11539 & SS & 1 & 1 & X85829 & & & \\
\hline 11984 & SS & 4 & 1 & $\mathrm{X} 85855$ & & X85865 & \\
\hline $12067 \ddagger$ & SS & $4 \mathrm{~b}$ & 1 & X85830 & X86997 & X85856 & X85882 \\
\hline 12352 & SS & 4 & 1 & X85831 & & & \\
\hline 12621 & SS & 4 & 1 & X85832 & & & \\
\hline $4789 / 85 \ddagger$ & SS & $1 / 2 \mathrm{~b}$ & 1 & $\mathrm{X} 85833$ & $\mathrm{X} 86998$ & & \\
\hline $604 / 86 \ddagger$ & SS & 4 & 1 & X85834 & $\mathrm{X} 86999$ & $\mathrm{X} 85866$ & \\
\hline $12664 / 86 \ddagger$ & SS & 4 & 1 & X85835 & & & X85894 \\
\hline $391 / 88 \ddagger$ & SS & $4 \mathrm{~b}$ & 1 & X85836 & & & \\
\hline $7382 / 88 \ddagger$ & SS & $4 \mathrm{~b}$ & 1 & X85837 & & & \\
\hline $429 / 89 \ddagger$ & SS & $4 b$ & 1 & X85838 & & & \\
\hline $12705 / 89$ & SS & 1 & 1 & X85839 & & $\mathrm{X} 85869$ & \\
\hline $13408 / 89 \ddagger$ & SS & $4 b$ & 1 & $\mathrm{X} 85840$ & $\mathrm{X} 87000$ & & \\
\hline $14614 / 89 \ddagger$ & SS & $4 \mathrm{~b}$ & 1 & X85841 & & & \\
\hline $14676 / 89$ & SS & 1 & 1 & X85842 & & X85870 & \\
\hline $15632 / 89 \ddagger$ & SS & 4 & 1 & $\mathrm{X} 85843$ & & & \\
\hline $\mathrm{H} 10 \ddagger$ & ICB & $4 b$ & 1 & X85844 & X87001 & X85936 & \\
\hline $652 \ddagger$ & ICB & $4 b$ & 1 & X85845 & $\mathrm{X} 87002$ & & X85895 \\
\hline Ep2 $\ddagger$ & ICB & $4 b$ & 1 & X85846 & $\mathrm{X} 87003$ & & X85896 \\
\hline $245-1 \ddagger$ & RVAU & 1 & 1 & $\mathrm{X} 85847$ & & & \\
\hline $315-5 \ddagger$ & RVAU & 1 & 1 & X85848 & & & \\
\hline $85 \mathrm{~F} / 1$ & RVAU & 4 & 1 & $\mathrm{X} 85849$ & & & \\
\hline $1169 \mathrm{~F} 1.2 \ddagger$ & RVAU & 4 & 1 & $\mathrm{X} 85850$ & X87004 & & \\
\hline R33 & RVAU & 1 & 1 & X85851 & & & \\
\hline T31‡ & RVAU & 1 & 1 & X85852 & X87005 & & X85897 \\
\hline $444 \ddagger$ & $\mathrm{CC}$ & $4 b$ & 1 & X85853 & & & \\
\hline $5001 \ddagger$ & SS & $1 / 2 a$ & 2 & $\mathrm{X} 85924$ & X86989 & X85879 & \\
\hline 5700 & SS & 1 & 2 & X85925 & & & X85898 \\
\hline 7785 & SS & 1 & 2 & X85909 & & X85877 & X85899 \\
\hline 9495 & SS & 1 & 2 & X85926 & & & X85900 \\
\hline 10472 & SS & 1 & 2 & X85910 & & & \\
\hline 10585 & SS & 1 & 2 & $\mathrm{X} 85927$ & & & \\
\hline 11049 & SS & 1 & 2 & X85928 & & & \\
\hline 11463 & SS & 1 & 2 & X85911 & & & \\
\hline 11464 & SS & 1 & 2 & X85912 & & & \\
\hline 11819 & SS & 1 & 2 & X85929 & & & \\
\hline 65500 & SS & 1 & 2 & $\mathrm{X} 85930$ & $\mathrm{X} 86980$ & X85939 & X85901 \\
\hline
\end{tabular}


Table 1. (cont.)

\begin{tabular}{|c|c|c|c|c|c|c|c|}
\hline \multirow[t]{2}{*}{ Strain } & \multirow{2}{*}{$\begin{array}{l}\text { Source or } \\
\text { reference* }\end{array}$} & \multirow[t]{2}{*}{ Serotype } & \multirow{2}{*}{$\begin{array}{l}\text { Sequence } \\
\text { type }\end{array}$} & \multicolumn{4}{|c|}{ Analysed genes } \\
\hline & & & & hly & $f l a A$ & $i a p$ & $23 S$ rRNA \\
\hline $4772 / 83 \ddagger$ & SS & $1 / 2$ & 2 & X85931 & X86981 & & \\
\hline $14387 / 89$ & ss & 1 & 2 & $\mathrm{X} 85932$ & & & \\
\hline 5.1.1 & RVAU & 1 & 2 & X85933 & & & \\
\hline 12.1.1‡ & RVAU & 1 & 2 & X85934 & & & \\
\hline 18.1.2 & RVAU & 1 & 2 & X85913 & & & \\
\hline 45.1.1 & RVAU & 1 & 2 & $\mathrm{X} 85940$ & & & \\
\hline 57.1.1 & RVAU & 1 & 2 & X85941 & & & \\
\hline 64.1.1‡ & RVAU & 1 & 2 & X85942 & $\mathrm{X} 86982$ & X85875 & \\
\hline $103-5 \ddagger$ & RVAU & 1 & 2 & X85943 & X86983 & & X85902 \\
\hline 202.2 .3 & RVAU & 1 & 2 & X85914 & & & \\
\hline $204.2 .3 \ddagger$ & RVAU & 1 & 2 & $\mathrm{X} 85915$ & X86984 & & X85903 \\
\hline 206.1 .1 & RVAU & 1 & 2 & X85935 & & & \\
\hline 2947 & RVAU & 1 & 2 & X85916 & & & \\
\hline $1156 \mathrm{~F} 1.4 \ddagger$ & RVAU & 1 & 2 & X85917 & & & \\
\hline B46 & RVAU & 1 & 2 & X85944 & & & \\
\hline $\mathrm{K} 26 \ddagger$ & RVAU & 1 & 2 & X85908 & X86979 & $\mathrm{X} 85876$ & X85904 \\
\hline K69‡ & RVAU & 1 & 2 & X85945 & $\mathrm{X} 86985$ & & X85905 \\
\hline $441 \ddagger$ & $\mathrm{CC}$ & $1 / 2 c$ & 2 & $\mathrm{X} 85918$ & & $\mathrm{X} 85938$ & \\
\hline $442 \ddagger$ & $\mathrm{CC}$ & 3 & 2 & X85919 & & & \\
\hline $15526 \ddagger$ & $\mathrm{CC}$ & $1 / 2 \mathrm{a}$ & 2 & $\mathrm{X} 85920$ & X86986 & $\mathrm{X} 85878$ & X85906 \\
\hline NCTC7973‡ & NCTC & $1 / 2 a$ & 2 & X85921 & $\mathrm{X} 86987$ & & \\
\hline 443 & $\mathrm{CC}$ & $4 a$ & 3 & $\mathrm{X} 85813$ & X86991 & $\mathrm{X} 85880$ & X85907 \\
\hline ATCC19114 & ATCC & $4 a$ & 3 & X85814 & $\mathrm{X} 86990$ & X85881 & X85937 \\
\hline LO28 & IP & $1 / 2 c$ & 2 & IP* & $\mathrm{X} 86988$ & & \\
\hline EGD & Ref. & $1 / 2 a$ & 2 & Ref.* & & Ref.* & \\
\hline
\end{tabular}

* Sources: SS, W. Frederiksen and P. Gerner-Schmidt, Statens Seruminstitut, Copenhagen, Denmark; ATCC, American Type Culture Collection; CC, Culture Collection, University of Gothenburg, Gothenburg, Sweden; NCTC, National Collection of Type Cultures, Colindale, UK; RVAU, B. Nørrung, Department of Veterinary Microbiology, The Royal Veterinary and Agricultural University, Copenhagen, Denmark; ICB, J.-C. Piffaretti, Instituto Cantonale Bacteriologico, Lugano, Switzerland (obtained via B. Nørrung); IP, P. Cossart, Institut Pasteur, Paris, France: the sequence of the bly gene is from Mengaud et al. (1988); Ref., the sequences of the bly and iap gene segments are from Doman \& Chakraborty (1989) and Köhler et al. (1990), respectively.

† Flagellar antigens have not been determined for all isolates.

$\ddagger$ The nucleotide sequence of the bly gene was determined by Rasmussen et al. (1991).

type 2 strains, a few strain-specific differences were found (Table 3).

Finally, a 99 bp region (position 1587-1685, not shown in Fig. 1) downstream of the L. monocytogenes specific region of iap was sequenced for six strains of type 1 and one type 2 strain. All sequences in this region were identical to that of strain EGD.

\section{The 235 rRNA gene}

The $230 \mathrm{bp}$ region from positions 1350 to 1580 of the $L$. monocytogenes $23 \mathrm{~S}$ rRNA gene (Thompson et al., 1992) was sequenced in 27 strains (16 type 1, nine type 2, and two type 3 strains). This region was selected because it contains some of the more variable parts (V9 and V10) of the rRNA operon (Lane, 1991). By our approach, where we obtained an average sequence for the six copies (Michel \&
Cossart, 1992) of the rRNA operon, we did not find any differences between or within the sequence types. This does not exclude, however, that in the analysed region there are differences within single copies of the rRNA genes, as such differences would not be detected by our approach. Recently, Czajka et al. (1993) sequenced most of the $16 \mathrm{~S} r R N A$ gene of a limited number of $L$. monocytogenes strains by an approach similar to ours and they did find differences in the V2 region between four serotype 1/2a isolates and also between these and a single serotype $4 \mathrm{~b}$ isolate. This shows that intraspecies differences do occur in the rRNA genes.

Compared with the sequence reported by Thompson et al. (1992), all strains analysed in this study were found to have two additional Cs at position 1411. This difference may be explained by the fact that they sequenced a single, cloned rDNA copy. 
Table 2. General nucleotide differences among the three DNA sequence types in the $180 \mathrm{bp}$ region of the flaA gene and the $150 \mathrm{bp}$ region of the hly gene analysed

\begin{tabular}{|c|c|c|c|}
\hline \multirow[t]{2}{*}{ Position } & \multicolumn{3}{|c|}{$\begin{array}{l}\text { Nucleotide in } \\
\text { sequence type: }\end{array}$} \\
\hline & 1 & 2 & 3 \\
\hline \multicolumn{4}{|l|}{ fla $A^{*}$} \\
\hline 648 & C & $\mathrm{T}$ & C \\
\hline 666 & $\mathrm{C}$ & $\mathrm{T}$ & $\mathrm{C}$ \\
\hline 711 & $\mathrm{~T}$ & A & $\mathrm{T}$ \\
\hline \multirow[t]{2}{*}{735} & $\mathrm{C}$ & $\mathrm{C}$ & $\mathrm{T}$ \\
\hline & 1 & $2 \ddagger$ & 3 \\
\hline \multicolumn{4}{|l|}{$h l y \dagger$} \\
\hline 1773 & $\mathrm{~T}$ & A & $\mathrm{T}$ \\
\hline 1776 & $\mathrm{C}$ & $\mathrm{T}$ & $\mathrm{T}$ \\
\hline 1806 & $\mathrm{C}$ & C & $\mathrm{T}$ \\
\hline 1809 & $\mathrm{~T}$ & $\mathrm{C}$ & $\mathrm{C}$ \\
\hline 1827 & A & $\mathrm{C} / \mathrm{A}$ & A \\
\hline 1845 & $\mathrm{~T}$ & C & $\mathrm{T}$ \\
\hline 1857 & $\mathrm{C}$ & $\mathrm{T}$ & $\mathrm{C}$ \\
\hline 1860 & G & A & G \\
\hline 1884 & C & $\mathrm{T}$ & $\mathrm{T}$ \\
\hline
\end{tabular}

* The analysed region is from position 622 to 803 [numbering according to Dons et al. (1992)].

† The analysed region is from position 1740 to 1890 [numbering according to Mengaud et al. (1988)].

$\ddagger$ The bly sequence type 2 includes the two subtypes, $2 \mathrm{~A}$ and $2 \mathrm{~B}$, described in Rasmussen et al. (1991).

\section{The listeriolysin gene}

To clarify whether the bly gene also exists in three types and to search for more possible variants, a $150 \mathrm{bp}$ region of the gene was analysed for 39 strains in addition to the 36 strains analysed in our previous study (Rasmussen et $a l ., 1991)$. As for the fla $A$ and the iap genes, the two serotype 4a strains did form a third separate sequence type (Table 2). All other strains were found to have a sequence of one of the two other sequence types previously observed (Rasmussen et al., 1991). Furthermore, we did not find deviations from the full correspondence among the groups of strains formed according to the bly gene and the two other genes. Three strains had strain-specific nucleotide differences at various positions (Table 3).

\section{Evolutionary lines of $L$. monocytogenes}

This study confirms our earlier work (Rasmussen et al., 1991) which showed that the bly gene of L. monocytogenes exists in distinct, well-conserved types. However, in addition to the two types previously found, a third type containing serotype $4 \mathrm{a}$ strains was identified. Moreover, an identical pattern was found for the $f a A$ and the iap
Table 3. Strain-specific nucleotide differences in the flaA, iap and hly genes

The normal nucleotides and deduced amino acids, if the differences cause a change, are shown in parentheses.

\begin{tabular}{|c|c|c|c|c|}
\hline Gene & Isolate & Position* & Nucleotide & $\begin{array}{c}\text { Amino acid } \\
\text { change }\end{array}$ \\
\hline \multirow[t]{3}{*}{$f l a A$} & 5001 & 690 & $\mathrm{~T}(\mathrm{C})$ & - \\
\hline & 443 & 622 & $G(C)$ & Glu (Gln) \\
\hline & 1028 & 758 & $T(C)$ & Ile (Thr) \\
\hline \multirow[t]{10}{*}{$i a p$} & 5001 & 1414 & $G(A)$ & - \\
\hline & & 1513 & $C(T)$ & - \\
\hline & 7785 & 1408 & $G(A)$ & - \\
\hline & 11463 & 1513 & $C(T)$ & - \\
\hline & & 1525 & $\mathrm{~T}(\mathrm{C})$ & - \\
\hline & & 1546 & $C(T)$ & - \\
\hline & 65500 & 1396 & $G(A)$ & - \\
\hline & & 1402 & $\mathrm{~T}(\mathrm{~A})$ & - \\
\hline & 15526 & 1408 & $G(A)$ & - \\
\hline & & 1441 & $\mathrm{~T}(\mathrm{~A})$ & - \\
\hline \multirow[t]{3}{*}{$h l y$} & 7595 & 1764 & $G(A)$ & - \\
\hline & 11984 & 1789 & $C(G)$ & Gln (Glu) \\
\hline & 206.1 .1 & 1778 & $\mathrm{~T}(\mathrm{C})$ & Phe (Ser) \\
\hline
\end{tabular}

* The positions of the fla $A$, iap and bly genes are according to Dons et al. (1992), Köhler et al. (1990) and Mengaud et al. (1988), respectively.

genes and there was full correspondence among the grouping of strains according to the three genes analysed. As the bly and iap genes are located 30-1225 kbp apart on the genetic map of the L. monocytogenes genome (Michel \& Cossart, 1992), and the $f l a A$ gene is not located adjacent to the two other genes (data not shown), it is most likely that the pattern of at least three distinct types is a characteristic feature of a larger part of the L. monocytogenes genome, conceivably the complete chromosome. Thus, there may be three or possibly more distinct evolutionary lines of $L$. monocytogenes. The presence of distinct evolutionary lines is substantiated by MLEE (Bibb et al., 1990; Piffaretti et al., 1989), RFLP (Vines et al., 1992), and RAPD profiling (Mazurier \& Wernars, 1992) data, but with these methods, however, only two evolutionary lines have been indicated so far. Our data further indicate that recombination among $L$. monocytogenes strains of different evolutionary lines is rare.

Serotype $4 \mathrm{a}$ strains of sequence type 3 have been characterized in only a few earlier studies using other techniques. In the MLEE study by Piffaretti et al. (1989), the single serotype $4 \mathrm{a}$ isolate included grouped together with 4b isolates, whereas Mazurier \& Wernars (1992) found that all five serotype $4 \mathrm{a}$ isolates included in their RAPD analysis formed a separate group. It has further been found that the $\operatorname{lma} A$ probe which is highly specific for $L$. monocytogenes does not hybridize to serotype 4 a isolates (Notermans et al., 1989). These data support the 


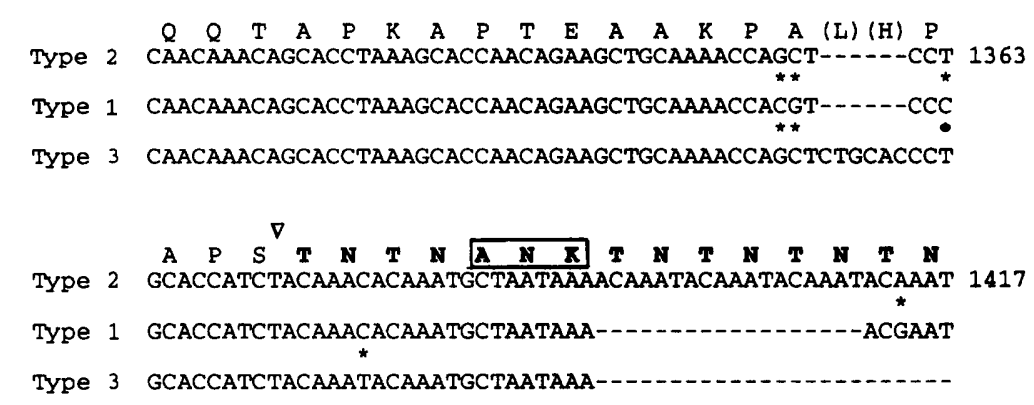

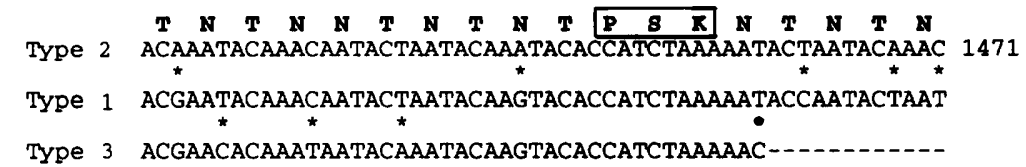

$\begin{array}{llllllllllllllllll}\mathbf{S} & \mathbf{N} & \mathbf{T} & \mathbf{N} & \mathbf{T} & \mathbf{N} & \mathbf{T} & \mathbf{N} & \mathbf{S} & \mathbf{N} & \mathbf{T} & \mathbf{N} & \mathbf{A} & \mathbf{N} & \mathbf{Q} & \mathrm{G} & \mathbf{S} & \mathbf{S}\end{array}$

Type 2 TCAAATACTAATACGATACAAACTCAAATACGATTGCTAATCAAGGTTCTTCC 1525

Type 1 ACAAACTCCAATACGAATACAAACTCAAATACGAATGCTAATCAAGGTTCTTCT

Type 3 -... ACAAATACAAACACGAACACAAATGCTAACCAAGGTTCTTCC

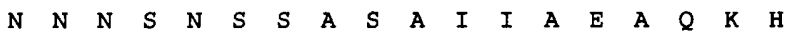

Type 2 AACAATAACAGCAATTCAAGTCAAGTGCTATATTGCTGAAGCTCAAAAACAC 1579

Type 1 AaCAATAACAGCAATTCAAGTGCGAGTGCTATTATTGCTGAAGCTCAAAAACAC

Type 3 AACAATAACAGCAATTCAAGTGCAAGTGCTATTATTGCAGAaGCTCAAAAACAC

Type 2 CTTGgaAaAgCTT

Type 1 CTTGgAaAAGCTT

Type 3 CTTGGAA
Fig. 1. Nucleotide sequences of sequence type 1 (12067), type 2 (EGD) and type 3 (443) strains from position 1316-1586 of the iap gene. This part covers the regions 1 and 2 in the analysis of the gene. Differences are indicated by asterisks. For the type 3 strain, 443, the sequence of the four TN repeats distal to the PSK motif is tentatively located to obtain the least number of nucleotide sequence differences. The amino acid sequence of EGD is shown in single-letter code above the nucleotide sequences. The amino acids shown in parentheses are deduced from the sequence of isolate $\mathbf{4 4 3}$. Dashes indicate alignment gaps. The repeat region is in bold, the ANK and PSK motifs are in boxes, and the separation between regions 1 and 2 is indicated by $\nabla$.

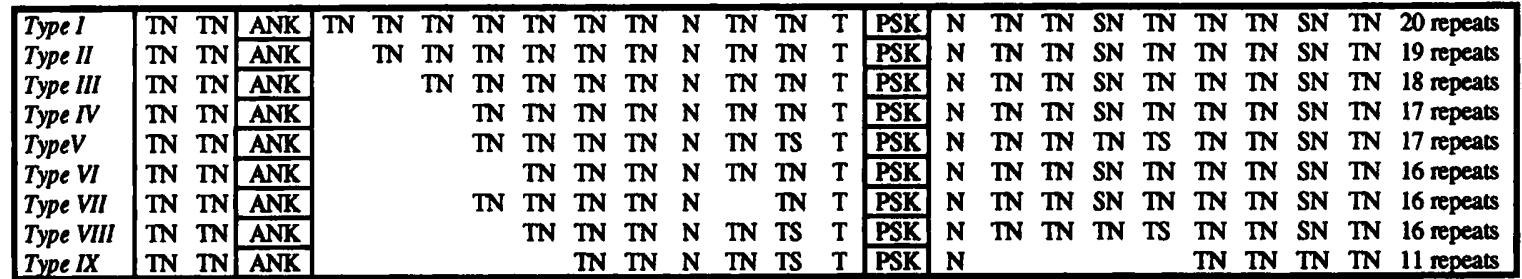

Fig. 2. Types of TN repeat structures found in the polypeptide sequence deduced from the iap genes of the 26 isolates analysed (cf. Table 4). The types are divided according to the number, arrangements and composition of repeats. One letter amino acid codes are used.

hypothesis that serotype $4 \mathrm{a}$ isolates form a distinct homogeneous group. It is uncertain whether other less frequent serotypes not included in this study will group in one of the three identified DNA sequence types or form additional separate groups.

Based on the isolates for which the flagellar antigens have been determined, there is a correlation between sequence types and flagellar antigens. Sequence type 1 isolates are of serotype $b$ ( $A B C H$-antigens), whereas sequence type 2 isolates are of serotypes a or c (AB or $\mathrm{BD} \mathrm{H}$-antigens, respectively), the only exception being the two sequence type 3 isolates of serotype $4 a$. In accordance with the correlation between sequence types and flagellar antigens, all the human clinical isolates, which most likely are of flagellar b types (McLauchlin, 1987), group in sequence type 1 , and the serotype $1 / 2$ isolates which may be expected to be of different flagellar serotypes fall into both sequence types 1 and 2 . The groups of the sequence types 1 and 2 thus correspond to groupings obtained by MLEE (Bibb et al., 1990), RAPD profiling (Mazurier \& Wernars, 1992), RFLP (Vines et al., 1992) and PFGE (Brosch et al., 1994).

A remarkably strong degree of conservation was found within each sequence type. At only two positions, in the 
Table 4. Correlation between number of $\mathrm{TN}$ repeats in the iap gene and sequence type. Repeat type is according to Fig. 2.

\begin{tabular}{|lcccc|}
\hline $\begin{array}{l}\text { Repeat } \\
\text { type }\end{array}$ & $\begin{array}{c}\text { No. of } \\
\text { repeats }\end{array}$ & $\begin{array}{c}\text { No. of } \\
\text { strains } \\
\text { analysed }\end{array}$ & Serotype* & $\begin{array}{c}\text { Sequence } \\
\text { type }\end{array}$ \\
\hline I & 20 & 1 & $1 / 2 \mathrm{c}$ & 2 \\
II & 19 & 1 & $1 / 2$ & 2 \\
II & 19 & 1 & $1 / 2 \mathrm{a}$ & 2 \\
III & 18 & 2 & $1 / 2$ & 2 \\
IV & 17 & 1 & $1 / 2$ & 2 \\
V & 17 & 4 & $1 / 2$ & 1 \\
VI & 16 & 1 & $1 / 2$ & 2 \\
VII & 16 & 1 & $1 / 2$ & 2 \\
VIII & 16 & 9 & 4 & 1 \\
VIII & 16 & 3 & $4 b$ & 1 \\
IX & 11 & 2 & $4 a$ & 3 \\
\hline
\end{tabular}

* For some strains the flagellar antigens were not determined.

iap gene for sequence type 1 strains and in the bly gene for sequence type 2 strains, were intra-sequence-type differences common to several strains found. More strikingly, in the total of approximately $23 \mathrm{~kb}$ sequenced in this study, as few as 16 strain-specific nucleotide differences (Table 3), corresponding to $0.69 \%$, were found. The degree of strain-specific differences varied among the sequence types, being $0 \cdot 15 \%$ for type 1 (13.0 kb analysed), $0.87 \%$ for type $2(9.1 \mathrm{~kb}$ analysed), and $0.87 \%$ for type $3(1.1 \mathrm{~kb}$ analysed). This variation among the sequence types is consistent with the MLEE data of Bibb et al. (1990), who found a higher genetic variability in ETGB which corresponds to the sequence type 2 than in ETGA.

In conclusion, L. monocytogenes has been shown to exist in at least three well-conserved evolutionary lines with a strong degree of conservation within those lines. The majority of the isolates group into two of the sequence types for which there is a correlation with flagellar antigens as well as grouping based on MLEE, RAPD, RFLP and PFGE.

\section{ACKNOWLEDGEMENTS}

We thank E. Hjerl-Hansen for skilled technical assistance; W. Frederiksen and P. Gerner-Schmidt, Statens Seruminstitut, Copenhagen, and B. Nørrung, Department of Veterinary Microbiology, Royal Veterinary and Agricultural University, for providing L. monocytogenes strains; D. B. Collinge for critically reading the manuscript; and Randi Brundstedt for the typing. This work was supported by the RVAU Centre for Food Research.

\section{REFERENCES}

Bibb, W. F., Gellin, B. G., Weaver, R., Schwartz, B., Plikaytis, B. D., Reeves, M. W., Pinner, R. W. \& Broome, C. V. (1990). Analysis of clinical and food-borne isolates of Listeria monocytogenes in the United States by multilocus enzyme electrophoresis and application of the method to epidemiologic investigations. Appl Environ Microbiol 56, 2133-2141.

Boerlin, P., Rocourt, J. \& Piffaretti, J.-C. (1991). Taxonomy of the genus Listeria by using multilocus enzyme electrophoresis. Int $J$ Syst Bacteriol 41, 59-64.

Brosch, R., Buchreiser, C. \& Rocourt, J. (1991). Subtyping of Listeria monocytogenes serovar $4 \mathrm{~b}$ by use of low-frequency-cleavage restriction endonucleases and pulsed-field gel electrophoresis. Res Microbiol 142, 667-675.

Brosch, R., Chen, J. \& Luchansky, J. B. (1994). Pulsed-field fingerprinting of Listeriae: identification of genomic divisions for Listeria monocytogenes and their correlation with serovar. Appl Environ Microbiol 60, 2584-2592.

Bubert, A., Kobhler, S. \& Goebel, W. (1992). The homologous and heterologous regions within the iap gene allow genus- and speciesspecific identification of Listeria spp. by polymerase chain reaction. Appl Environ Microbiol 58, 2625-2632.

Buchreiser, C., Brosch, R. \& Rocourt, J. (1991). Use of pulsed field gel electrophoresis to compare large DNA-restriction fragments of Listeria monocytogenes strains belonging to serogroups $1 / 2$ and 3 . Int J Food Microbiol 14, 297-304.

Czajka, J., Bsat, N., Piani, M., Russ, W., Sultana, K., Wiedmann, M., Whitaker, R. \& Batt, C. A. (1993). Differentiation of Listeria monocytogenes and Listeria innocua by $16 \mathrm{~S}$ rRNA genes and intraspecies discrimination of Listeria monocytogenes strains by random amplified polymorphic DNA polymorphisms. Appl Environ Microbiol 59, 304-308.

Doman, E. \& Chakraborty, T. (1989). Nucleotide sequence of the listeriolysin gene from a Listeria monocytogenes serotype 1/2a strain. Nucleic Acids Res 17, 6406.

Dons, L., Rasmussen, O. F. \& Olsen, J. E. (1992). Cloning and characterization of a gene encoding flagellin of Listeria monocytogenes. Mol Microbiol 6, 2919-2929.

Fleming, D. W., Cochi, S., MacDonald, K. L., Brandum, J., Hayes, P. S., Plikaytis, B. D., Holmes, M. B., Audurier, A., Broome, C. V. \& Reingold, A. L. (1985). Pasteurized milk as a vehicle of infection in an outbreak of listeriosis. $N$ Engl J Med 312, 404-407.

Jones, C. J. \& Aizawa, S.t. (1991). The bacterial flagellum and flagellar motor: structure, assembly and function. Adv Microb Physiol 32, 109-172.

Köhler, S., Leimeister-Wächter, M., Chakraborty, T., Lottspeich, F. \& Goebel, W. (1990). The gene coding for protein p 60 of Listeria monocytogenes and its use as a specific probe for Listeria monocytogenes. Infect Immun 58, 1943-1950.

Kuhn, M. \& Goebel, W. (1989). Identification of an extracellular protein of Listeria monocytogenes possibly involved in intracellular uptake by mammalian cells. Infect Immun 57, 55-61.

Lane, D. J. (1991). 16S/23S rRNA sequencing. In Nucleic Acid Techniques in Bacterial Systematics, pp. 115-176. Edited by E. Stackebrandt \& M. Goodfellow. New York: John Wiley \& Sons.

Linnan, M. J., Mascola, L., Xiao, D. L., Goulet, V., May, S., Salminer, C., Hird, D. W., Yonekura, L., Hayes, P., Weaver, R., Audurier, A., Plikaytis, B. D., Fannin, S. L., Kleks, A. \& Broome, C. V. (1988). Epidemic listeriosis associated with Mexican-style cheese. $N$ Engl J Med 319, 823-828.

McLauchlin, J. (1987). Listeria monocytogenes, recent advances in the taxonomy and epidemiology of listeriosis in humans. $J A p p l$ Bacteriol 63, 1-11.

Macnab, R. (1992). Genetics and biogenesis of bacterial flagella. Annu Rev Genet 26, 131-158.

Masten, B. J. \& Joys, T. M. (1993). Molecular analysis of the Salmonella g... flagellar antigen complex. J Bacteriol 175, 5359-5365. 
Mazurier, S.-I. \& Wernars, K. (1992). Typing of Listeria strains by random amplification of polymorphic DNA. Res Microbiol 143, 499-505.

Mengaud, J., Vicente, M. F., Chenevert, J., Moniz Pereira, J., Geoffroy, C., Gicquel-Sanzey, B., Baquero, F., Perez-Diaz, J.-C. \& Cossart, P. (1988). Expression in Escherichia coli and sequence analysis of the listeriolysin $\mathrm{O}$ determinant of Listeria monocytogenes. Infect Immun 56, 766-772.

Michel, E. \& Cossart, P. (1992). Physical map of the Listeria monocytogenes chromosome. J Bacteriol 174, 7098-7103.

Notermans, S., Chakraborty, T., Leimeister-Wachter, M., Dufrenne, J., Heuvelman, K. J., Maas, H., Jansen, W., Wernars, K. \& Guinee, P. (1989). Specific gene probe for detection of biotyped and serotyped Listeria strains. Appl Environ Microbiol 55, 902-906.

Piffaretti, J.-C., Kressebuch, H., Aeschbacher, M., Bille, J., Bannerman, E., Musser, J. M., Selander, R. K. \& Rocourt, J. (1989). Genetic characterization of clones of the bacterium Listeria monocytogenes causing epidemic disease. Proc Natl Acad Sci US A 86, 3818-3822.

Rasmussen, O. F., Beck, T., Olsen, J. E., Dons, L. \& Rossen L. (1991). Listeria monocytogenes isolates can be classified into two major types according to the sequence of the listeriolysin gene. Infect Immun 59, 3945-3951.

Schoenhals, G. \& Whitfeld, C. (1993). Comparative analysis of flagellin sequences from Eschericbia coli strains possessing serologically distinct flagellar filaments with a shared complex surface pattern. J Bacteriol 175, 5395-5402.

Seelinger, H. P. R. \& Jones, D. (1986). Genus Listeria Pirie 1940, $383^{\mathrm{AL}}$. In Bergey's Manual of Systematic Bacteriology, vol. 2, pp. 1235-1245. Edited by P. H. A. Sneath, N. S. Mair, N. E. Sharpe \& J. G. Holt. Baltimore: Williams \& Wilkins.

Tabouret, M., De Rycke, J. \& Dubray, G. (1992). Analysis of surface proteins of Listeria in relation to species, serovar and pathogenicity. $J$ Gen Microbiol 138, 743-753.

Thompson, D. E., Balsdon, J. T., Cai, J. \& Collins, M. D. (1992). Studies on the ribosomal RNA operons of Listeria monocytogenes. FEMS Microbiol Lett 96, 219-224.

Vines, A., Reeves, M. W., Hunter, S. \& Swaminathan, B. (1992). Restriction fragment length polymorphism in four virulenceassociated genes of Listeria monocytogenes. Res Microbiol 143, 281-294.

Received 6 December 1994; revised 26 May 1995; accepted 30 May 1995. 